\title{
Colony Management System
}

National Cancer Institute

\section{Source}

National Cancer Institute. Colony Management System. NCI Thesaurus. Code C64342.

A multi-user relational database management system for managing animal colonies in a research environment. 